\title{
Trapping Mobile Pt Species by PdO in Diesel Oxidation \\ Catalysts: Smaller is Better
}

\author{
Haifeng Xiong ${ }^{1}$, Eric Peterson ${ }^{1}$, Gongshin $\mathrm{Qi}^{2}$ and Abhaya K. Datye*, \\ ${ }^{1}$ Department of Chemical \&Biological Engineering and Center for Microengineered Materials, \\ University of New Mexico, Albuquerque, New Mexico 87131, USA. \\ ${ }^{2}$ General Motors Global R\&D, 30500 Mound Rd., Warren, MI 48090, USA. \\ *Corresponding author. Tel.: +1 505277 0477; fax: +1 505277 5433; Email:datye@unm.edu(A.K. \\ Datye)
}

\begin{abstract}
Pt is an active catalyst for treatment of diesel exhaust emissions but is known to sinter and form large particles under oxidizing conditions. Pd is added to suppress the sintering of $\mathrm{Pt}$ and improve the performance of the Pt catalysts through the formation of a Pt-Pd alloy. In a previous study, using model catalysts, we demonstrated that mobile Pt species can diffuse on the surface and get trapped on PdO particles, leading to the formation of metallic Pt-Pd alloys in flowing air at $650{ }^{\circ} \mathrm{C}$. In this work we explore the implications of this trapping phenomenon to powder catalysts. We physically mixed $\mathrm{Pt} / \mathrm{MgAl}_{2} \mathrm{O}_{4}$ and $\mathrm{PdO} / \mathrm{La}-\mathrm{Al}_{2} \mathrm{O}_{3}$ catalyst powders and aged them at $800{ }^{\circ} \mathrm{C}$ in air. Mobile Pt species emitted from the $\mathrm{Pt} / \mathrm{MgAl}_{2} \mathrm{O}_{4}$ migrated through the vapor phase and were trapped by $\mathrm{PdO}$ nanoparticles located on the $\mathrm{La}-\mathrm{Al}_{2} \mathrm{O}_{3}$ support. Since the Pt moved from the $\mathrm{MgAl}_{2} \mathrm{O}_{4}$ support to the $\mathrm{PdO}$, we infer that $\mathrm{PdO}$ is better at trapping Pt than the $\mathrm{MgAl}_{2} \mathrm{O}_{4}$ support. We also investigated the effect of $\mathrm{PdO}$ particle size on the trapping efficiency for Pt. It was found that small PdO particles were more effective, leading to smaller size of Pt-Pd particles as confirmed by electron microscopy, $\mathrm{x}$-ray diffraction and reactivity for methane oxidation.
\end{abstract}

Keywords: Diesel oxidation catalyst; Bimetallic Pt-Pd; Trapping Pt; Particle size effect 


\section{Introduction}

Pt is a precious metal $(0.003 \mathrm{ppb}$ in the earth's crust)and is among the most active elements for $\mathrm{NO}$ oxidation in diesel oxidation catalysts (DOCs). However, Pt nanoparticles (NPs) sinterwhen the catalysts are used at high temperature underoxidizing conditions.[1] The mechanism of sintering is Ostwald ripening,[2] which results is the loss of active surface area and drop in reactivity after use.Due to the high cost and low abundance of Pt, it is important to develop strategies to improve the durability of Pt catalysts by slowing the rate of sintering of Pt. We have recently demonstrated that the formation of a volatile oxide of $\mathrm{Pt}$ plays a significant role in the degradation of Pt catalysts when heated in air at $800{ }^{\circ} \mathrm{C}$.[3] The high vapor pressure of $\mathrm{Pt}$ oxides is a significant contributor to the rates of catalyst sintering. A recent report suggests that $\mathrm{MgAl}_{2} \mathrm{O}_{4}$ as a support could help slow the rates of Pt sintering because it is possible to stabilize small Pt particles due to a strong affinity between Pt and the (111) facets of the $\mathrm{MgAl}_{2} \mathrm{O}_{4}$ support.[4]This previous study found that after aging in air at $800{ }^{\circ} \mathrm{C}$, a significant fraction of the Pt was present in the form of large particles as detected by XRD. The authors reasoned this growth of Pt occurred because of the limited availability of suitable sites on the spinel to stabilize Pt. In this study we explore whether the presence of $\mathrm{PdO}$ might help to trap this mobile Pt that leads to the growth of large particles.

It is known that the addition of a second metal, for example Pd,leads to improvements in the durability of Pt catalysts, the mechanisms are still a subject of study.[1,5]Pd has a very low vapor pressure under oxidizing conditions due to the formation of the stable oxide $\mathrm{PdO}$ and we see very little sintering of Pd only catalysts when heated in air at $800{ }^{\circ} \mathrm{C}$.[3] We have also found that the presence of Pt helps to keep Pd in metallic form,[6] and the Pd helps to lower the rates of emission of $\mathrm{Pt}$ to the vapor phase.[3] When Pt nanoparticles were deposited on a planar model $\mathrm{SiO}_{2}$ supportas a separate phase, heating for only 2 minutes at $650{ }^{\circ} \mathrm{C}$ in air caused the formation of bimetallic PtPd particles.[7] This previous work demonstrates that $\mathrm{Pt}$ species are mobile andcan be effectively trapped by $\mathrm{PdO}$ at high temperatures in air, forming bimetallic PtPd particleswhich are thermodynamically more stable.[7]

The migration and vapor phase transport of precious metals in automotive exhaust catalysts has been documented in the literature. Cavataio et al. [8]pointed out that trace amounts of precious metals were transported from Pt-based DOC catalysts to the SCR catalyst, negatively impacting the performance of the SCR catalyst. Yu-Yao and Kummer[9]reported that they were able to prepare low concentration precious metal catalysts via vapor phase transport from a metal foil to an alumina or ceria-alumina support. The transport of precious metals has also been found to lead to formation of alloys and bimetallic nanoparticles, as in the case of physically mixed Pt and $\mathrm{Pd}[10]$ catalysts and also Pt, and $\mathrm{Rh}$ catalysts[11]. In this previous work, the results were influenced by the catalyst formulation, for example the same nominal ratio of Pt and Pd gave very different extent of volatilization and transport. The role of particle size and morphology was not explicitly studied.

The objective of the present work is to investigate the trapping capability of $\mathrm{PdO}$ by physically mixing $\mathrm{Pt} / \mathrm{MgAl}_{2} \mathrm{O}_{4}$ andPdO/La- $\mathrm{Al}_{2} \mathrm{O}_{3}$ catalysts, followed by agingin flowing air at $800{ }^{\circ} \mathrm{C}$. Detailed STEM-EDX analysis was used to investigate the location and composition of Pt-containing particles. We separately aged the $\mathrm{PdO} / \mathrm{La}-\mathrm{Al}_{2} \mathrm{O}_{3}$ to generatePdO particlesof differing size, so the role of particle size on the trapping capability of Ptcould be studied. 
Methane oxidation was used as a probe reaction and the results show that smaller PdO crystallites are more effective at trapping the mobile Pt, which appears to move from the spinel phase via vapor phase transport and is captured on the PdO particles.

\section{Experimental}

\section{Catalyst preparation and aging}

La-alumina was obtained from W. R. Grace (MI-386), contained 4 wt. $\% \mathrm{La}_{2} \mathrm{O}_{3}$, and had a BET surface area of $176 \mathrm{~m}^{2} \mathrm{~g}^{-1} \cdot \mathrm{MgAl}_{2} \mathrm{O}_{4}$ spinel support (surface area: $132 \mathrm{~m}^{2} \mathrm{~g}^{-1}$ ) was synthesized following the method reported in the literature.[4]The $\mathrm{Pt} / \mathrm{La}-\mathrm{Al}_{2} \mathrm{O}_{3}$ and $\mathrm{Pt} / \mathrm{MgAl}_{2} \mathrm{O}_{4}$ catalysts $(1 \mathrm{wt} . \% \mathrm{Pt})$ were prepared by incipient wetness by using an aqueous solution of chloroplatinic acid $\left(8 \mathrm{wt} . \% \mathrm{H}_{2} \mathrm{PtCl}_{6}\right)$. The as-prepared catalyst materials were calcined at $450{ }^{\circ} \mathrm{C}$ for $5 \mathrm{~h}$ in flowing air.

The $\mathrm{PdO} / \mathrm{La}-\mathrm{Al}_{2} \mathrm{O}_{3}$ catalysts $(2 \mathrm{wt} . \% \mathrm{Pd})$ were prepared by incipient wetness using a 10 wt. $\%$ palladium(II) nitrate solution in $10 \mathrm{wt} . \%$ nitric acid. This sample was subjected to different thermal pretreatment to vary the $\mathrm{PdO}$ particle size. The $\mathrm{PdO} / \mathrm{La}-\mathrm{Al}_{2} \mathrm{O}_{3}$ catalysts were calcined in air at $350^{\circ} \mathrm{C}(6 \mathrm{~h})$ and $800^{\circ} \mathrm{C}(10 \mathrm{~h}$ and $50 \mathrm{~h}$, respectively). These catalysts were denoted as $\mathrm{PdO} / \mathrm{La}-\mathrm{Al}_{2} \mathrm{O}_{3}-1, \mathrm{PdO} / \mathrm{La}-\mathrm{Al}_{2} \mathrm{O}_{3}-2$ and $\mathrm{PdO} / \mathrm{La}-\mathrm{Al}_{2} \mathrm{O}_{3}-3$, respectively.

To investigate the trapping capability of PdOon Pt with different $\mathrm{PdO}$ sizes, $\mathrm{Pt} / \mathrm{MgAl}_{2} \mathrm{O}_{4}$ was physically mixed with the above threePdO/La- $\mathrm{Al}_{2} \mathrm{O}_{3}$ catalyst with a mass ratio of $1: 1$, respectively. The physical mixture wasthen aged at $800{ }^{\circ} \mathrm{C}$ for $10 \mathrm{~h}$ inflowing air $(100$ $\mathrm{mL} / \mathrm{min}$ ). For comparison purposes, monometallic $\mathrm{Pt} / \mathrm{MgAl}_{2} \mathrm{O}_{4}$ and $\mathrm{Pt} / \mathrm{La}-\mathrm{Al}_{2} \mathrm{O}_{3}$ catalystswere also aged at $800{ }^{\circ} \mathrm{C}$ for $10 \mathrm{~h}$ in flowingair $(100 \mathrm{~mL} / \mathrm{min})$.

\section{Characterization}

XRD patterns for the samples were recorded with a Rigaku Smart Lab diffratometer using $\mathrm{Cu} \mathrm{K} \mathrm{K}_{\alpha}$ radiation and a Ni filter. $\mathrm{N}_{2}$ physisorption was performed on a Quantachrome Autosorb-1. Scanning electron microscopy (SEM) was performed on a Hitachi S-5200. High resolution transmission electron microscopy was performed using a JEOL 2010F microscope. The powders were deposited on holey carbon support films after being dispersed in ethanol.

\section{Methane oxidation}

Methane oxidation[12] was used as a probe reaction to investigate the reactivity of these catalysts. We selected this reaction since it operates under lean conditions, where metallic $\mathrm{Pd}$ easily transforms into PdO. Hence, the reaction is useful for determining the extent of Pt-Pd contact, since the bimetallic nanoparticles remain in metallic form under oxidizing conditions [6].The catalytic activity for methane oxidation over the physical mixtures $\left(\mathrm{Pt} / \mathrm{MgAl}_{2} \mathrm{O}_{4}-\mathrm{PdO} / \mathrm{La}-\mathrm{Al}_{2} \mathrm{O}_{3}\right.$ ) catalyst was measured in a plug-flow quartz tube reactor. $\mathrm{A}$ powder sample of 20 mgwas placed in the middle of the reactor.Gasflow rates was measured by mass flow controllers. Reaction products were analyzed by an online micro-GC (Agilent 490). The reactant gas mixture contained $2 \% \mathrm{CH}_{4}, 5 \% \mathrm{O}_{2}$ and $\mathrm{He}$ as balance. Light-off 
measurements were carried out with a heating rate of $2 \mathrm{~K} \mathrm{~min}^{-1}$ from $100{ }^{\circ} \mathrm{C}$ to $600{ }^{\circ} \mathrm{C}$, with aGHSV of $30000 \mathrm{~h}^{-1}$.

\section{Results and discussion}

\subsection{Sintering behavior of $\mathrm{Pt}$ nanoparticles supported on $\mathrm{MgAl}_{2} \mathrm{O}_{4}$ and $\mathrm{La}_{-} \mathrm{Al}_{2} \mathrm{O}_{3}$ at high temperaure in oxidation conditions}

The sintering behavior of monometallic $\mathrm{Pt}$ nanoparticles supported on $\mathrm{MgAl}_{2} \mathrm{O}_{4}$ and La- $\mathrm{Al}_{2} \mathrm{O}_{3}$ was first investigated. The XRD patterns of Pt supported on $\mathrm{MgAl}_{2} \mathrm{O}_{4}$ and $\mathrm{La}-\mathrm{Al}_{2} \mathrm{O}_{3}$ before and after aging are shown in Fig. 1. No diffraction peaks corresponding to Pt nanoparticles was found on the XRD patterns of the fresh Pt catalysts, indicating that Pt NPs are highly dispersed on the support. However, the sharp diffraction peaks corresponding to Pt crystallites are observed on the XRD patterns of $\mathrm{Pt} / \mathrm{MgAl}_{2} \mathrm{O}_{4}$ and $\mathrm{Pt} / \mathrm{La}-\mathrm{Al}_{2} \mathrm{O}_{3}$ catalysts after aging. Calculation based on the Scherrer equation indicated that the average crystallite sizes of Pt after aging for both of the catalysts are larger than $500 \mathrm{~nm}$. This means that the Pt catalysts on $\mathrm{MgAl}_{2} \mathrm{O}_{4}$ and La- $\mathrm{Al}_{2} \mathrm{O}_{3}$ sintered significantly suggesting that these supports do not stabilize Pt when exposed to high temperaturesunder oxidizing conditions.

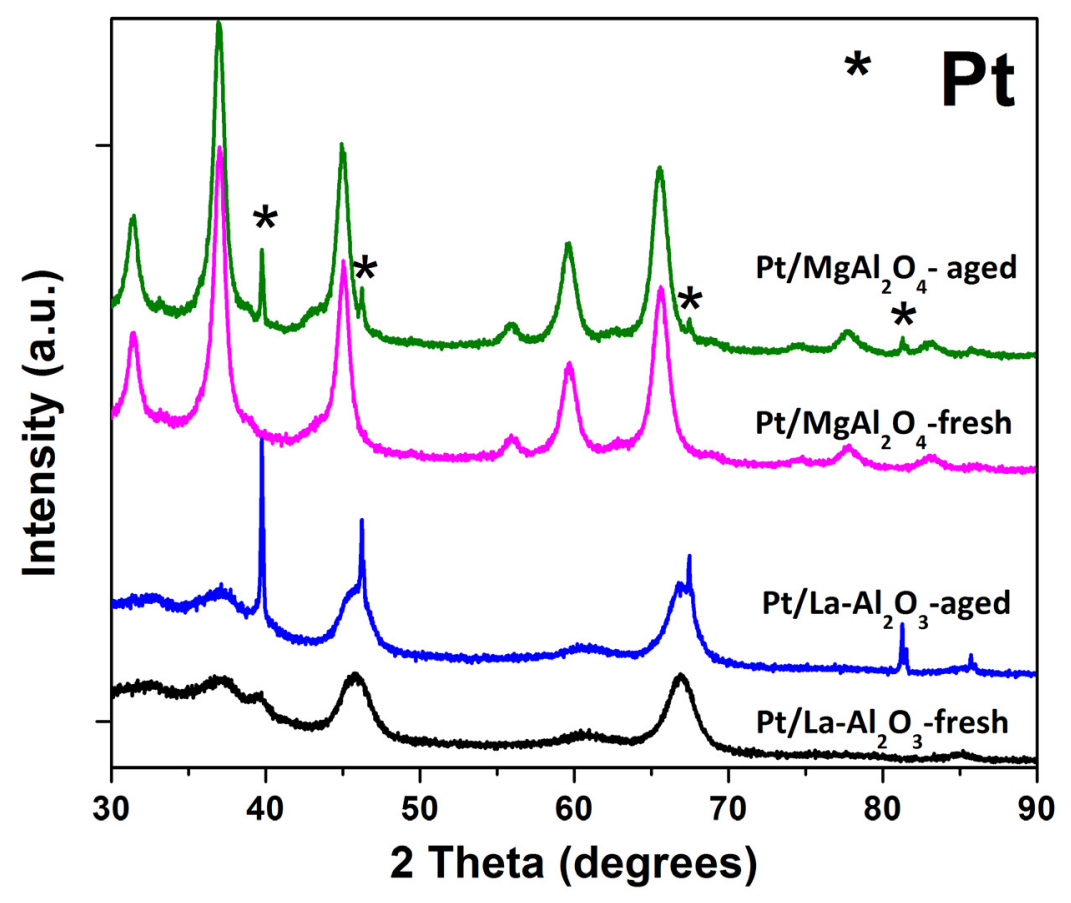

Fig. 1. XRD patternsof $\mathrm{Pt}$ nanoparticles supported on $\mathrm{La}-\mathrm{Al}_{2} \mathrm{O}_{3}$ and $\mathrm{MgAl}_{2} \mathrm{O}_{4}$ before and after aging at $800{ }^{\circ} \mathrm{C}$ for $10 \mathrm{~h}$ in air.Scherrer analysis indicates the particle size of $\mathrm{Pt}>500 \mathrm{~nm}$ ie too large to be accurately determined by this technique.

The representative electron microscope images (SEM/TEM/STEM) of Pt/La- $\mathrm{Al}_{2} \mathrm{O}_{3}$ catalyst before and after aging in air are shown in Fig. 2. The Pt nanoparticles on the 
$\mathrm{Pt} / \mathrm{La}-\mathrm{Al}_{2} \mathrm{O}_{3}$ catalyst before the high temperature treatment are small and the Pt sizes are in the range of $1-5 \mathrm{~nm}$ before aging (Fig. 2a). However, after aging at $800{ }^{\circ} \mathrm{C}$ in air, micrometer-scale Pt particles (1-4 $\mu \mathrm{m})$ are formed (Fig. 2b and c). These results confirm the observations of the $\mathrm{Pt} / \mathrm{La}-\mathrm{Al}_{2} \mathrm{O}_{3}$ via XRD indicating the severe sintering seen after aging the catalysts in flowing air for 10 hours.
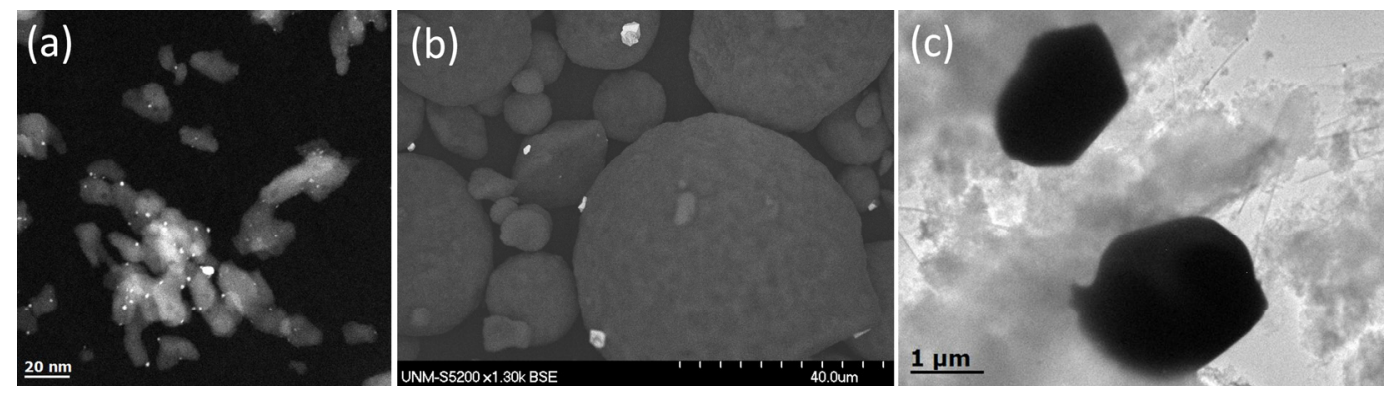

Fig. 2.Representative electron microscope images of $\mathrm{Pt}$ nanoparticles supported on $\mathrm{La}_{-}-\mathrm{Al}_{2} \mathrm{O}_{3}$ : (a) HAADF-STEM and (b) SEM image of as-prepared $1 \mathrm{wt} . \% \mathrm{Pt} / \mathrm{La}-\mathrm{Al}_{2} \mathrm{O}_{3}$; (c) TEM image of the same catalyst after aging at $800^{\circ} \mathrm{C}$ for $10 \mathrm{~h}$ in air.

The representative TEM/STEM images of Pt/ $\mathrm{MgAl}_{2} \mathrm{O}_{4}$ catalyst before and after aging in air are shown in Fig. 3. The Pt nanoparticle sizes on the $\mathrm{Pt} / \mathrm{MgAl}_{2} \mathrm{O}_{4}$ catalyst are less than 1 $\mathrm{nm}$ in diameter before aging (Fig. 3a). After aging at $800{ }^{\circ} \mathrm{C}$ in air, we see micrometer-scale $\mathrm{Pt}$ particles $(0.5-1 \mu \mathrm{m})$ on the $\mathrm{Pt} / \mathrm{MgAl}_{2} \mathrm{O}_{4}$ catalyst (Fig. $3 \mathrm{~b}$ and c). However, we note that some Pt particles with size of $<1 \mathrm{~nm}$ still remain on the spinel support (Fig. 3d). Based on the distribution and density of these small Pt particles on spinel, and the morphology of the underlying support, we cannot infer the surface facets that might stabilize these small particles. The earlier study of $\mathrm{Li}$ et al.[4]concluded that the small Pt particles were present on the the $\mathrm{MgAl}_{2} \mathrm{O}_{4}$ (111) facets. The majority of the Pt is present in the form of large particles on the $\mathrm{Pt} / \mathrm{MgAl}_{2} \mathrm{O}_{4}$ catalyst and we conclude that this catalyst also sintered significantly after aging under oxidizing conditions. 

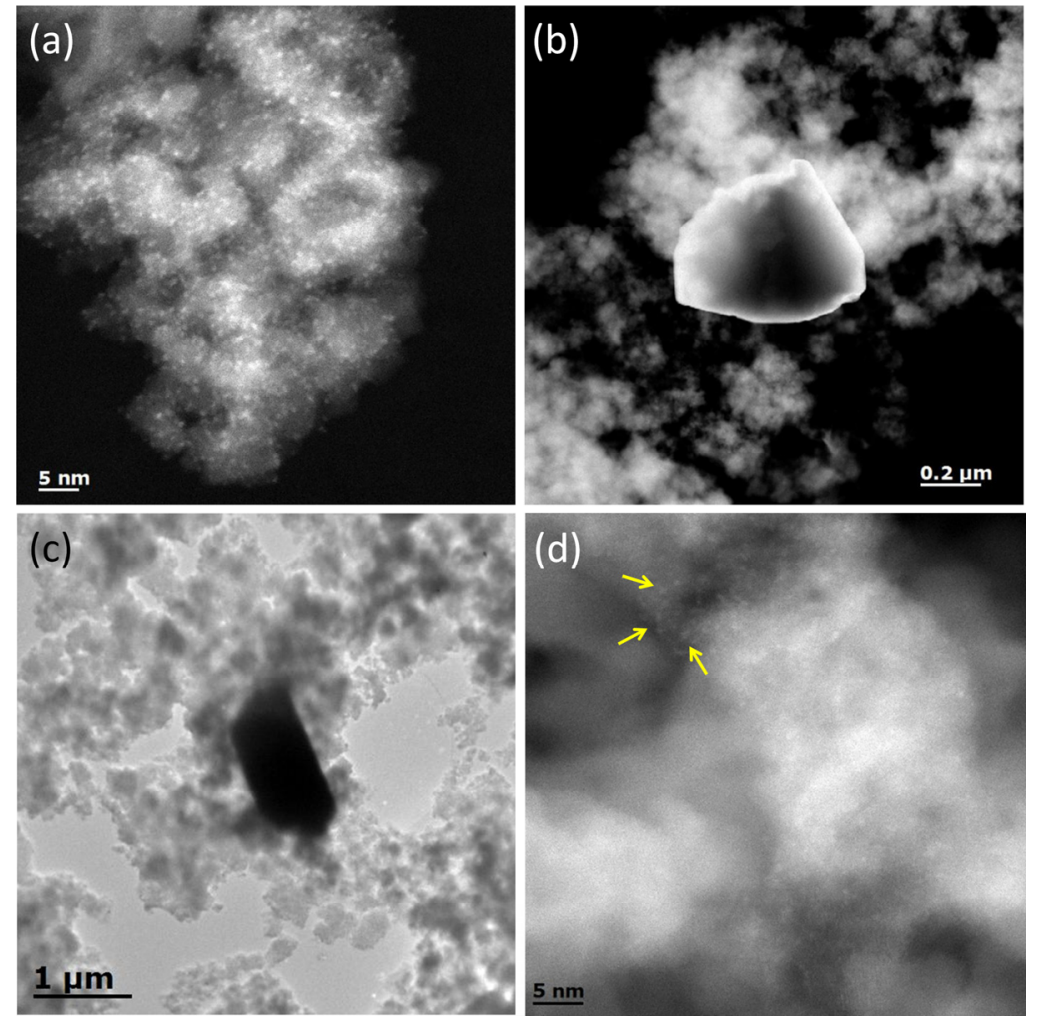

Fig. 3. Representative electron microscope images of Pt nanoparticles supported on $\mathrm{MgAl}_{2} \mathrm{O}_{4}$ : (a) fresh 1 wt.\%Pt/ $\mathrm{MgAl}_{2} \mathrm{O}_{4}$; (b), (c) and (d) 1 wt.\%Pt/ $\mathrm{MgAl}_{2} \mathrm{O}_{4}$ after aging at $800{ }^{\circ} \mathrm{C}$ for $10 \mathrm{~h}$ in air (arrows showing the Pt nanoparticles).

\subsection{Preparation and characterization of $\mathrm{PdO} / \mathrm{La}-\mathrm{Al}_{2} \mathrm{O}_{3}$ catalysts with different $\mathrm{PdO}$ particle sizes}

$\mathrm{PdO} / \mathrm{La}-\mathrm{Al}_{2} \mathrm{O}_{3}$ catalysts with different $\mathrm{PdO}$ particle sizes were prepared by varying the pretreatment of the catalyst. The XRD patterns of the three catalysts are shown in Fig. 4. The diffraction peaks corresponding to $\mathrm{PdO}$ are presented and the main phases on the three catalysts are $\mathrm{PdO}$ and $\mathrm{La}-\mathrm{Al}_{2} \mathrm{O}_{3}$. The sharper the diffraction peak of $\mathrm{PdO}$, the larger are the $\mathrm{PdO}$ nanoparticles (Fig. 4b).
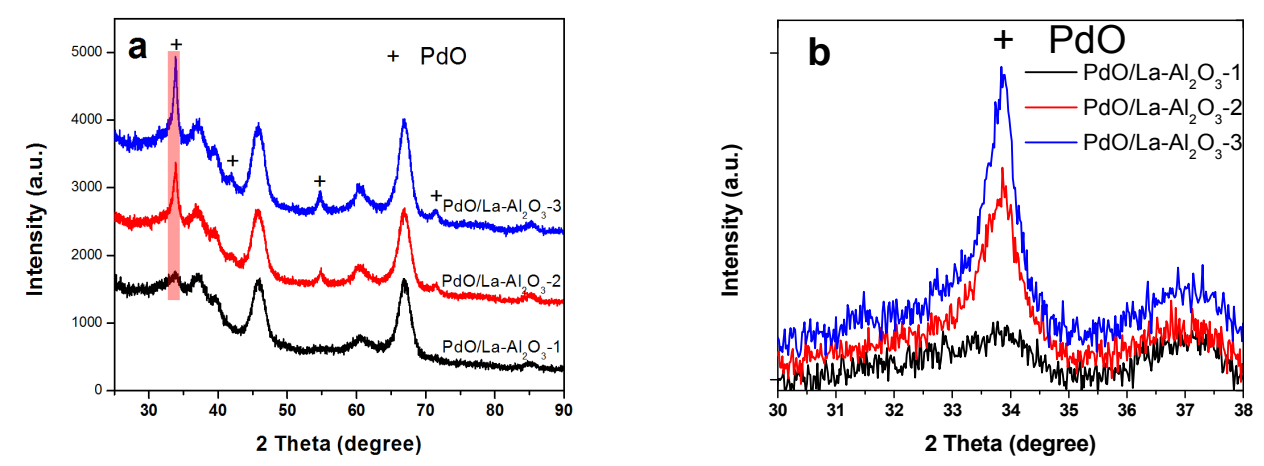

Fig. 4.(a) XRD patternsof $\mathrm{Pd} / \mathrm{La}-\mathrm{Al}_{2} \mathrm{O}_{3}$ with different $\mathrm{PdO}$ particle sizes; (b) the expanded XRD patterns of three $\mathrm{PdO} / \mathrm{La}-\mathrm{Al}_{2} \mathrm{O}_{3}$ over $30-38^{\circ}$ (shaded rectangle in a). 
Representative STEM images of the $\mathrm{PdO} / \mathrm{La}-\mathrm{Al}_{2} \mathrm{O}_{3}$ catalysts with different $\mathrm{PdO}$ particle sizes are shown in Fig. 5. The $\mathrm{PdO} / \mathrm{La}-\mathrm{Al}_{2} \mathrm{O}_{3}-1$ presents the $\mathrm{PdO}$ particles with around $1 \mathrm{~nm}$ (Fig. 5a). The $\mathrm{PdO} / \mathrm{La}-\mathrm{Al}_{2} \mathrm{O}_{3}-2$ showed that the $\mathrm{PdO}$ particle sizes are5-10 nm and these particles have rough irregular surface consistent with the images seen from oxide particles (Fig. 5b). The PdO particle sizes on $\mathrm{PdO} / \mathrm{La}-\mathrm{Al}_{2} \mathrm{O}_{3}-3$ are $10-200 \mathrm{~nm}$, much larger than those in the previously described samples (Fig. $5 \mathrm{c}$ and d).
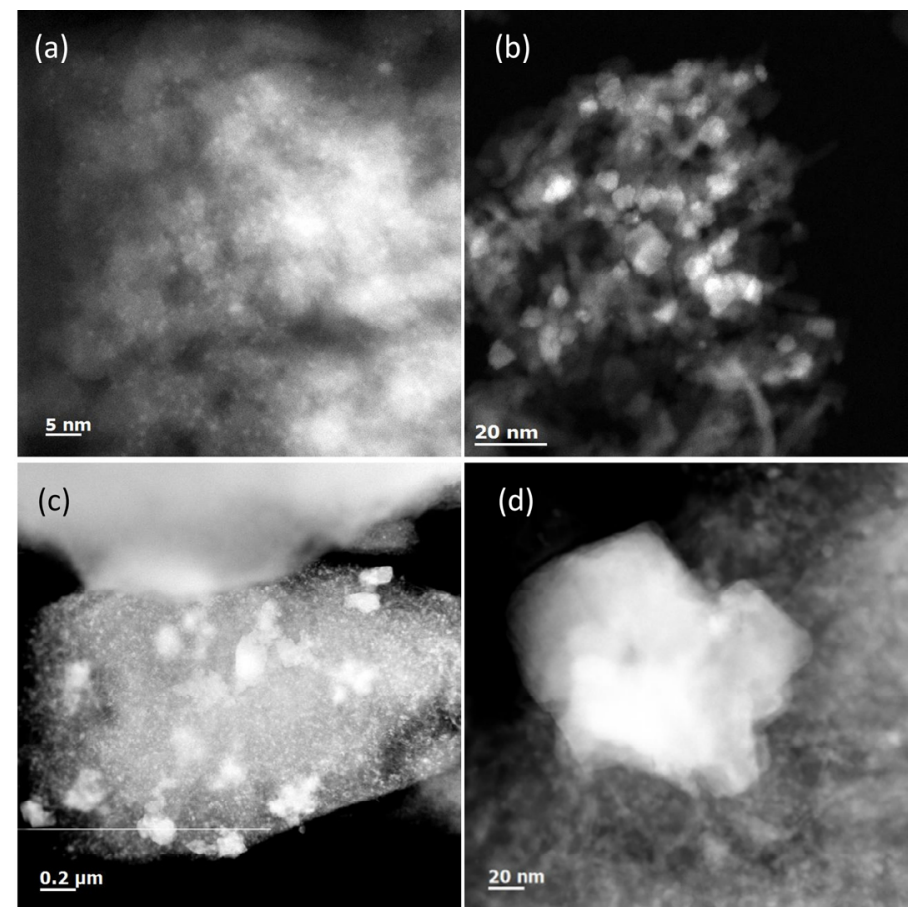

Fig. 5.STEM images of $\mathrm{PdO} / \mathrm{La}-\mathrm{Al}_{2} \mathrm{O}_{3}$ with different $\mathrm{PdO}$ particle sizes: (a) $\mathrm{PdO} / \mathrm{La}-\mathrm{Al}_{2} \mathrm{O}_{3}-1$; (b) $\mathrm{PdO} / \mathrm{La}-\mathrm{Al}_{2} \mathrm{O}_{3}-2$; (c) and (d)PdO/La- $\mathrm{Al}_{2} \mathrm{O}_{3}-3$.

\subsection{Characterization of physical mixtures $\left(\mathrm{Pt} / \mathrm{MgAl}_{2} \mathrm{O}_{4}+\mathrm{PdO} / \mathrm{La}-\mathrm{Al}_{2} \mathrm{O}_{3}\right)$ after aging at $800{ }^{\circ} \mathrm{C}$ in air}

The XRD patterns of three physically mixed samples after aging at $800{ }^{\circ} \mathrm{C}$ in air are shown in Fig. 6. It can be seen that after aging at $800{ }^{\circ} \mathrm{C}$ for $10 \mathrm{~h}$ the main phases for the three samples includePtPd, $\mathrm{PdO}$ and $\mathrm{MgAl}_{2} \mathrm{O}_{4}$. Moreover, it is noteworthy that the diffraction peak corresponding to PtPd becomes sharper with the increase of initial PdO particle size, indicating that larger PdO leads to the formation of larger PtPd particles after mixing and aging. We also see the absence of a metallic Pt peak, suggesting that most of the Pt migrated to the alumina support and was converted to the Pt-Pd alloy. 


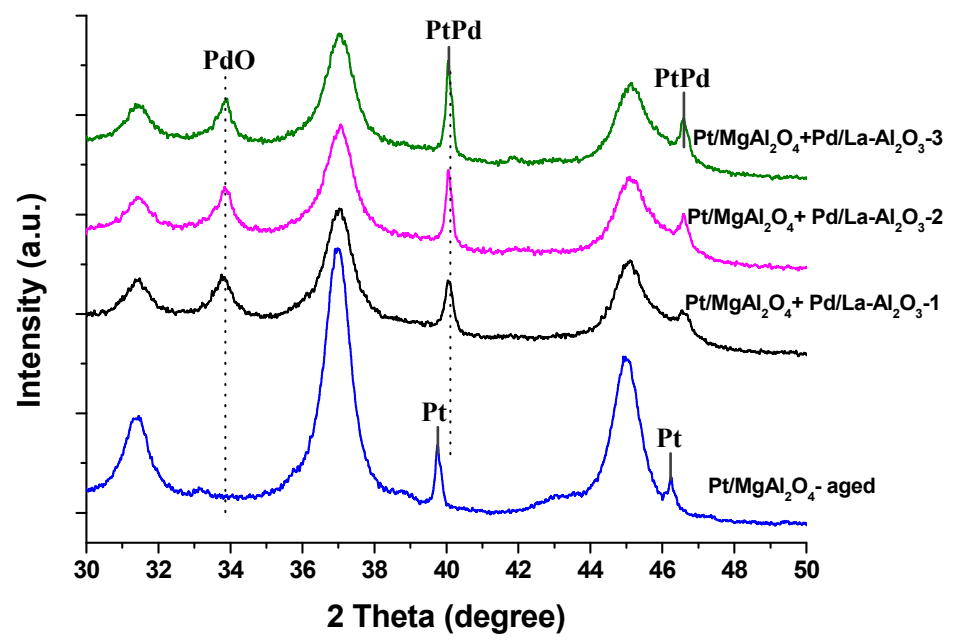

Fig. 6.XRD patternsof three physical mixtures after aging at $800^{\circ} \mathrm{C}$ for $10 \mathrm{~h}$ in air.

Rietveld refinement analysis confirmed that the catalyst with smaller initialPdOcrystallite size also led to smaller metallicPtPdcrystallites (Table 1). With the increase in initialPdO particle size, the average crystallite size ofPtPd particles increased. We also see an increase in the area of the Pt-Pd peak relative to the prominent reflection at $2 \theta=37^{\circ}$ which serves as an internal standard. Likewise, we see less residual PdOin the sample after the aging of the physically mixed samples.

Table 1

$\mathrm{X}$-ray diffraction analysis data of three physical mixtures after aging at $800{ }^{\circ} \mathrm{C}$ for $10 \mathrm{~h}$ in air

\begin{tabular}{|c|c|c|c|c|c|c|}
\hline \multirow[t]{2}{*}{ Catalyst } & \multirow{2}{*}{$\begin{array}{l}\mathrm{Pd} / \mathrm{Pt} \text { atomic } \\
\text { ratio }\end{array}$} & \multirow{2}{*}{$\begin{array}{l}\text { Initial PdO } \\
\text { size }(\mathrm{nm})\end{array}$} & \multicolumn{2}{|c|}{$\begin{array}{l}\text { Final particle } \\
\text { size }(\mathrm{nm})\end{array}$} & \multicolumn{2}{|c|}{ Diffraction peak area ratio } \\
\hline & & & PtPd & $\mathrm{PdO}$ & $\mathrm{A}_{\mathrm{PtPd}(111)} / \mathrm{A}_{\text {spinel(311) }}$ & $\mathrm{A}_{\mathrm{PdO}(101)} / \mathrm{A}_{\text {spinel(311) }}$ \\
\hline $\mathrm{Pt} / \mathrm{MgAl}_{2} \mathrm{O}_{4}+\mathrm{PdO} / \mathrm{La}-\mathrm{Al}_{2} \mathrm{O}_{3}-1$ & 3.67 & $<5$ & 19.0 & 9.6 & 0.14 & 0.25 \\
\hline $\mathrm{Pt} / \mathrm{MgAl}_{2} \mathrm{O}_{4}+\mathrm{PdO} / \mathrm{La}-\mathrm{Al}_{2} \mathrm{O}_{3}-2$ & 3.67 & 5 & 21.8 & 10.2 & 0.16 & 0.24 \\
\hline $\mathrm{Pt} / \mathrm{MgAl}_{2} \mathrm{O}_{4}+\mathrm{PdO} / \mathrm{La}-\mathrm{Al}_{2} \mathrm{O}_{3}-3$ & 3.67 & 12 & 45.1 & 11.4 & 0.20 & 0.21 \\
\hline
\end{tabular}

Representative STEM images of the physical mixtures after aging at $800{ }^{\circ} \mathrm{C}$ for $10 \mathrm{~h}$ in air are shown in Fig. 7. Large bimetallic PtPd particles $(50-100 \mathrm{~nm})$ are formed on all the physicallymixed samples after aging and all these bimetallic PtPd particles are supported on La- $\mathrm{Al}_{2} \mathrm{O}_{3}$, rather than $\mathrm{MgAl}_{2} \mathrm{O}_{4}$, evidenced by STEM-EDX. However, there are very few of the large PtPd particles seen on $\mathrm{Pt} / \mathrm{MgAl}_{2} \mathrm{O}_{4}+\mathrm{PdO} / \mathrm{La}_{-}-\mathrm{Al}_{2} \mathrm{O}_{3}-1$ and the size of the PtPd particles seen on $\mathrm{Pt} / \mathrm{MgAl}_{2} \mathrm{O}_{4}-\mathrm{PdO} / \mathrm{La}_{-} \mathrm{Al}_{2} \mathrm{O}_{3}-1$ is comparatively smaller than on the other two samples. Furthermore, it is observed that these large bimetallic particles havesmooth surfaces characteristic of a metallic phase, in contrast the oxide phase is very rough and irregular in shape as also seen previously.[7] 


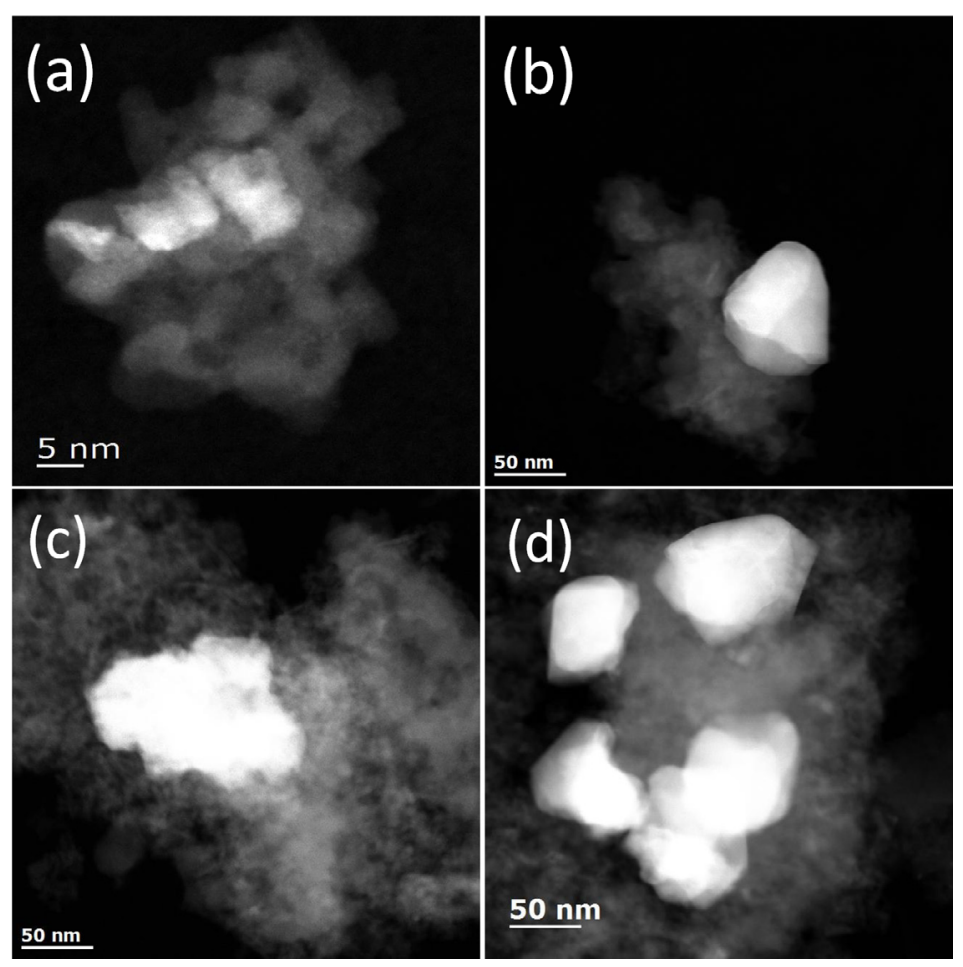

Fig. 7.STEM images of particles on the physical mixtures after aging at $800{ }^{\circ} \mathrm{C}$ for $10 \mathrm{~h}$ : (a) and (b)

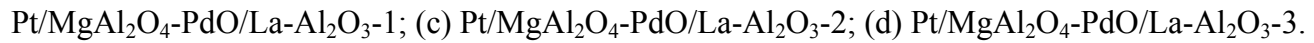

\subsection{Morphology and composition of PdO and PtPd particles revealed by STEM-EDX}

The morphology and composition of the large particles in the air-aged physical mixtures wasanalyzed by STEM-EDX, andthe STEM images and EDX results are shown in Fig. 8. It can be seen that the large particles contained both Pt and Pd, indicating that the Pt migrated to the PdO and was trapped there. The detailed spot EDX analysis showed that the composition of the large particles is not uniform, which means that the large particles are not single phase, explaining the discrepancy between XRD and TEM. Based on the composition and morphology of different locations on the large particles, we present a schematic illustrations of the structure of these large particles in the inset. These results indicated that the large bimetallic PtPdhave formed within the PdO, which now surrounds the metallic phase.

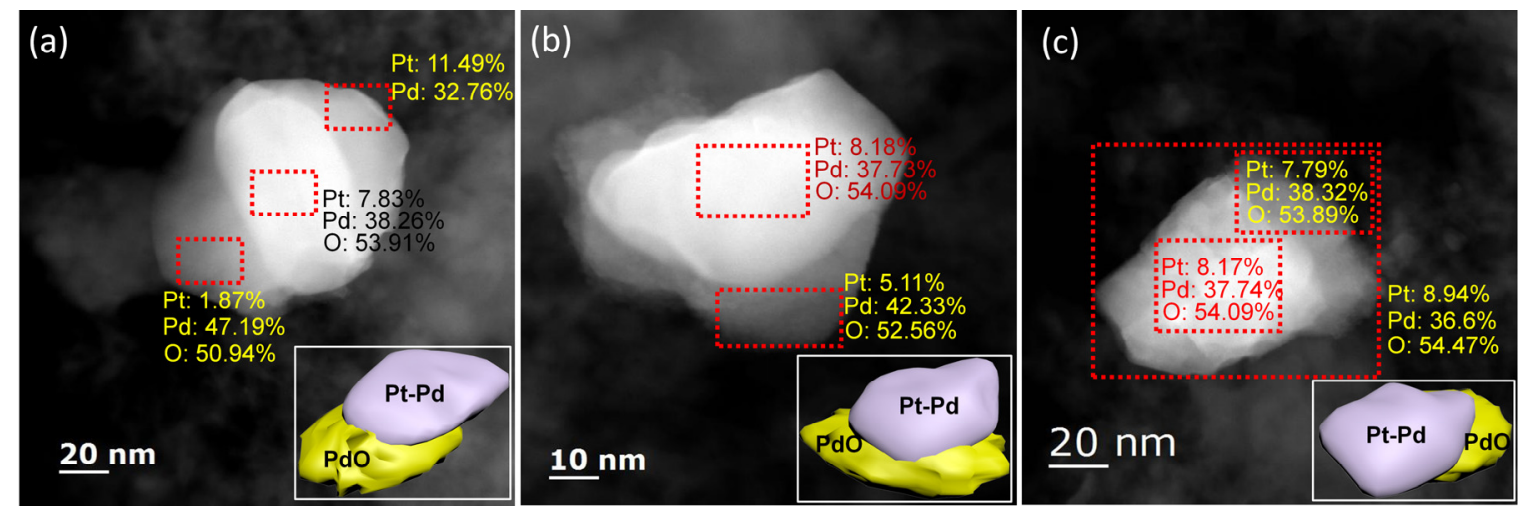

Fig. 8.STEM imagesand EDX analysis of physically mixed sample of $\mathrm{Pt} / \mathrm{MgAl}_{2} \mathrm{O}_{4}-\mathrm{PdO} / \mathrm{La}^{-} \mathrm{Al}_{2} \mathrm{O}_{3}$ after aging at $800{ }^{\circ} \mathrm{C}$ for $10 \mathrm{~h}$ in air (the inset is a schematic illustration of the locations of PtPd (light violet) 
and $\mathrm{PdO}$ (gold) particles).

\subsection{Methane oxidationas a probe reaction}

In order to investigate the trapping efficiency of $\mathrm{PdO}$ on $\mathrm{Pt}$ for the mixed three samples, a catalytic reaction was chosen to probe the active surface area of the Pt-Pd phase. We cannot use $\mathrm{CO}$ oxidation since it would cause reduction of the $\mathrm{PdO}$ to $\mathrm{Pd}$ metal. Methane oxidation performed under lean conditions will not lead to any reduction of the PdO or to oxidation of the Pt-Pd phase [13, 14]. The methane activity as a function of temperature for the aged $\mathrm{Pt} / \mathrm{MgAl}_{2} \mathrm{O}_{4}$ and theaged catalyst physical mixtures $\left(\mathrm{Pt} / \mathrm{MgAl}_{2} \mathrm{O}_{4}-\mathrm{PdO} / \mathrm{La}-\mathrm{Al}_{2} \mathrm{O}_{3}-1\right.$, $\mathrm{Pt} / \mathrm{MgAl}_{2} \mathrm{O}_{4}-\mathrm{PdO} / \mathrm{La}-\mathrm{Al}_{2} \mathrm{O}_{3}-2, \mathrm{Pt} / \mathrm{MgAl}_{2} \mathrm{O}_{4}-\mathrm{PdO} / \mathrm{La}-\mathrm{Al}_{2} \mathrm{O}_{3}-3$ ) is shown in Fig. 9. Fig. 9a shows the corresponding light-off curves for methane oxidation over $\mathrm{PdO} / \mathrm{La}-\mathrm{Al}_{2} \mathrm{O}_{3}$ before and after $\mathrm{H}_{2}$ reduction at $250{ }^{\circ} \mathrm{C}$ for $6 \mathrm{~h}$. From the curves, it can be seen that metallic $\mathrm{Pd}^{0}$ phase is more active than the PdOphase in methane oxidation at low temperatures. The superior activity of metallicPdoverPdO at low temperatures for methane oxidation has been reported in previous studies $[15,16]$, and it may be related to the unique sites created in coexisting Pd metal and oxide domains[17-20].At high temperatures the Pd transforms into $\mathrm{PdO}$ which then constitutes the catalytically active phase[21]. The light-off curves of three physical mixtures (Fig. $8 \mathrm{~b}$ and $\mathrm{c}$ ) in methane oxidation showed that higher activity was obtained for the physically mixedsample when $\mathrm{PdO} / \mathrm{La}-\mathrm{Al}_{2} \mathrm{O}_{3}$ catalyst with smaller $\mathrm{PdO}$ particle size used as a trap. Sincethe aged $\mathrm{Pt} / \mathrm{MgAl}_{2} \mathrm{O}_{4}$ presented negligible methane oxidation activity, it was concluded that the activity in these samples was mainly due to the presence ofPdO and PtPd phases.Based on the XRD results above, all the three mixtures consisted of similar sizedPdO after aging at $800{ }^{\circ} \mathrm{C}$ for $10 \mathrm{~h}$. Therefore, the differences in activity of the three catalyst must be due to the differences in the surface area of the metallic Pt-Pd. Since the same weight of catalyst was used for the runs reported in Fig. 8, the physically mixed samples contain only half as much PdO in 8 (b) as in 8(a). We conclude that the sample with smaller initial PdO particles provided higher methane oxidation activity due to the smaller crystallite size of Pt-Pd.
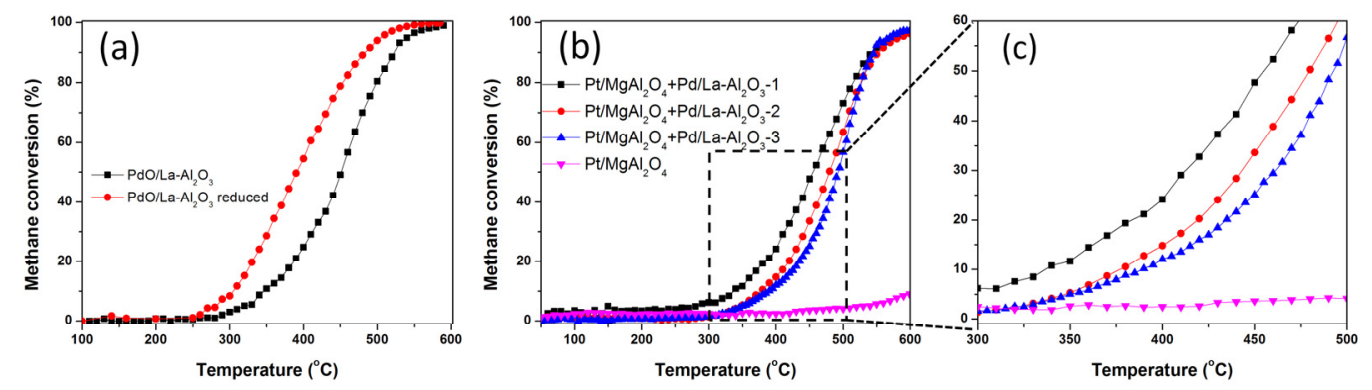

Fig. 9. Light-off curves for methane oxidation for catalysts (ramping rate: $2{ }^{\circ} \mathrm{C} / \mathrm{min}$ ): (a) $\mathrm{PdO} / \mathrm{La}-\mathrm{A}_{2} \mathrm{O}_{3}$ catalyst before and after reduction at $250{ }^{\circ} \mathrm{C}$ in $\mathrm{H}_{2}$ for $6 \mathrm{~h}$; (b) three physical mixtures of 1 wt.\% $\mathrm{Pt} / \mathrm{MgAl}_{2} \mathrm{O}_{4}$ and $1 \mathrm{wt} \% \mathrm{PdO} / \mathrm{La}-\mathrm{Al}_{2} \mathrm{O}_{3}$ after aging at $800^{\circ} \mathrm{Cin}$ air for $10 \mathrm{~h}$.

\section{Summary and Conclusions}

These results provide insight into the role of $\mathrm{PdO}$ in slowing the rate of sintering of $\mathrm{Pt}$ diesel oxidation catalysts. We show that the Pt sinters into large particles on both the 
$\mathrm{MgAl}_{2} \mathrm{O}_{4}$ and $\mathrm{La}-\mathrm{Al}_{2} \mathrm{O}_{3}$ supports, leading to formation of sub-micron sized Pt particles. When $\mathrm{PdO}$ nanoparticles were present in the catalyst, they were able to trap Pt even when these twocomponents were present in physically different powders. It is clear that the $\mathrm{MgAl}_{2} \mathrm{O}_{4}$ supportwas not able to completely 'hold on to' Ptduring heating in flowing air. Instead the Ptwas transportedthrough the vapor to the PdOphase which was present on the $\mathrm{La}-\mathrm{Al}_{2} \mathrm{O}_{3}$ support. We also demonstrated that $\mathrm{PdO}$ crystallite size plays a role, smaller initial particles resulted in smaller PtPdparticles withlarger amounts ofPdO left behind on the support. ThePtPd particles that are formed arepresent in the vicinity of excess PdOwhich has not reacted with the Pt after high temperature aging. The highPd:Pt ratio in the metallic core of the bimetallic particles suggest a fairly broad range of compositions where metallic particles of Pt:Pd may be stable under oxidizing conditions. The precise compositions of the phase stability envelope could not be determined in this study due to overlap with the PdO phase. The smaller Pt-Pd crystallite size after aging $(\sim 20 \mathrm{~nm})$ contrasts with the Pt particle size on the La-Al2O3 and $\mathrm{MgAl}_{2} \mathrm{O}_{4}$ phase $(>500 \mathrm{~nm})$ after similar aging in air. In summary, our results illustrate an important role played by PdOwhich acts as a trap helping to slow the sintering of Pt inPtPddiesel oxidation catalysts.The formation of the metallic Pt-Pd phase leads to the observed enhancement in methane oxidation activity compared to PdO.

\section{Acknowledgements}

Financialsupportfrom NSF GOALI grant CBET-1438765and General Motors Global R\&D and from the Center for Biorenewable Chemicals (CBiRC) supported by NSF under grant EEC-0813570 is gratefully acknowledged.We dedicate this contribution to the special issue in honor of Dr. Jens Rostrup Nielsen. The corresponding author (AKD) has interacted with Dr. Nielsen on numerous occasions, including during a sabbatical at HaldorTopsoe A/S. We congratulate Dr. Nielsen on a very distinguished and successful career and many scientific and technological accomplishments in the field of syngas generation and conversion.

\section{References}

[1] G.W. Graham, H.W. Jen, O. Ezekoye, R.J. Kudla, W. Chun, X.Q. Pan, R.W. McCabe, Effect of alloy composition on dispersion stability and catalytic activity for NO oxidation over alumina-supported Pt-Pd catalysts, Catal Lett, 116 (2007) 1-8.

[2] T.W. Hansen, A.T. DeLaRiva, S.R. Challa, A.K. Datye, Sintering of Catalytic Nanoparticles: Particle Migration or Ostwald Ripening?, Accounts of Chemical Research, 46 (2013) 1720-1730.

[3] T.R. Johns, R.S. Goeke, V. Ashbacher, P.C. Thüne, J.W. Niemantsverdriet, B. Kiefer, C.H. Kim, M.P. Balogh, A.K. Datye, Relating adatom emission to improved durability of Pt-Pd diesel oxidation catalysts, Journal of Catalysis, 328 (2015) 151-164.

[4] W.-Z. Li, L. Kovarik, D. Mei, J. Liu, Y. Wang, C.H.F. Peden, Stable platinum nanoparticles on specific MgA12O4 spinel facets at high temperatures in oxidizing atmospheres, Nat Commun, 4 (2013).

[5] M. Chen, L.D. Schmidt, Morphology and composition of $\mathrm{Pt} \cdot \mathrm{Pd}$ alloy crystallites on $\mathrm{SiO} 2$ in reactive atmospheres, Journal of Catalysis, 56 (1979) 198-218.

[6] T.R. Johns, J.R. Gaudet, E.J. Peterson, J.T. Miller, E.A. Stach, C.H. Kim, M.P. Balogh, A.K. Datye, Microstructure of Bimetallic Pt $\square$ Pd Catalysts under Oxidizing Conditions, ChemCatChem, 5 (2013) 
2636-2645.

[7] C. Carrillo, T.R. Johns, H. Xiong, A. DeLaRiva, S.R. Challa, R.S. Goeke, K. Artyushkova, W. Li, C.H. Kim, A.K. Datye, Trapping of Mobile Pt Species by PdO Nanoparticles under Oxidizing Conditions, The Journal of Physical Chemistry Letters, 5 (2014) 2089-2093.

[8] G. Cavataio, H.W. Jen, J.W. Girard, D. Dobson, J.R. Warner, C.K. Lambert, Impact and Prevention of Ultra-Low Contamination of Platinum Group Metals on SCR Catalysts Due to DOC Design, SAE Int. J. Fuels and Lubricants, 2 (2009) 204-216.

[9] Y.-F. Yu-Yao, J.T. Kummer, Low-concentration supported precious metal catalysts prepared by thermal transport, Journal of Catalysis, 106 (1987) 307-312.

[10] G.W. Graham, H. Sun, H.W. Jen, X.Q. Pan, R.W. McCabe, Aging-Induced Metal Redistribution in Bimetallic Catalysts, Catal Lett, 81 (2002) 1-7.

[11] J. Hangas, A.E. Chen, Comparative Analytical Study of Two Pt-Rh Three-way Catalysts, Catal Lett, 108 (2006) 103-111.

[12] J.G. McCarty, Kinetics of PdO combustion catalysis, Catalysis Today, 26 (1995) 283-293.

[13] K. Persson, K. Jansson, S.G. Järås, Characterisation and microstructure of Pd and bimetallic Pd-Pt catalysts during methane oxidation, Journal of Catalysis, 245 (2007) 401-414.

[14] A.T. Gremminger, H.W. Pereira de Carvalho, R. Popescu, J.-D. Grunwaldt, O. Deutschmann, Influence of gas composition on activity and durability of bimetallic Pd-Pt/A12O3 catalysts for total oxidation of methane, Catalysis Today, (2015).

[15] E.M. Cordi, J.L. Falconer, Oxidation of Volatile Organic Compounds on A12O3, Pd/A12O3, and PdO/A12O3Catalysts, Journal of Catalysis, 162 (1996) 104-117.

[16] M. Lyubovsky, L. Pfefferle, Complete methane oxidation over Pd catalyst supported on $\alpha$-alumina. Influence of temperature and oxygen pressure on the catalyst activity, Catalysis Today, 47 (1999) 29-44.

[17] A. Hellman, A. Resta, N.M. Martin, J. Gustafson, A. Trinchero, P.A. Carlsson, O. Balmes, R. Felici, R. van Rijn, J.W.M. Frenken, J.N. Andersen, E. Lundgren, H. Grönbeck, The Active Phase of Palladium during Methane Oxidation, The Journal of Physical Chemistry Letters, 3 (2012) 678-682.

[18] Y.-H. Chin, C. Buda, M. Neurock, E. Iglesia, Consequences of Metal-Oxide Interconversion for $\mathrm{C}-\mathrm{H}$ Bond Activation during CH4 Reactions on Pd Catalysts, Journal of the American Chemical Society, 135 (2013) 15425-15442.

[19] R. Burch, P.K. Loader, F.J. Urbano, Some aspects of hydrocarbon activation on platinum group metal combustion catalysts, Catalysis Today, 27 (1996) 243-248.

[20] N.M. Martin, M. Van den Bossche, A. Hellman, H. Grönbeck, C. Hakanoglu, J. Gustafson, S. Blomberg, N. Johansson, Z. Liu, S. Axnanda, J.F. Weaver, E. Lundgren, Intrinsic Ligand Effect Governing the Catalytic Activity of Pd Oxide Thin Films, ACS Catalysis, 4 (2014) 3330-3334.

[21] A.K. Datye, J. Bravo, T.R. Nelson, P. Atanasova, M. Lyubovsky, L. Pfefferle, Catalyst microstructure and methane oxidation reactivity during the $\mathrm{Pd}<->\mathrm{PdO}$ transformation on alumina supports, Applied Catalysis a-General ;, 198 (2000) 179-196. 


\section{Graphical abstract}

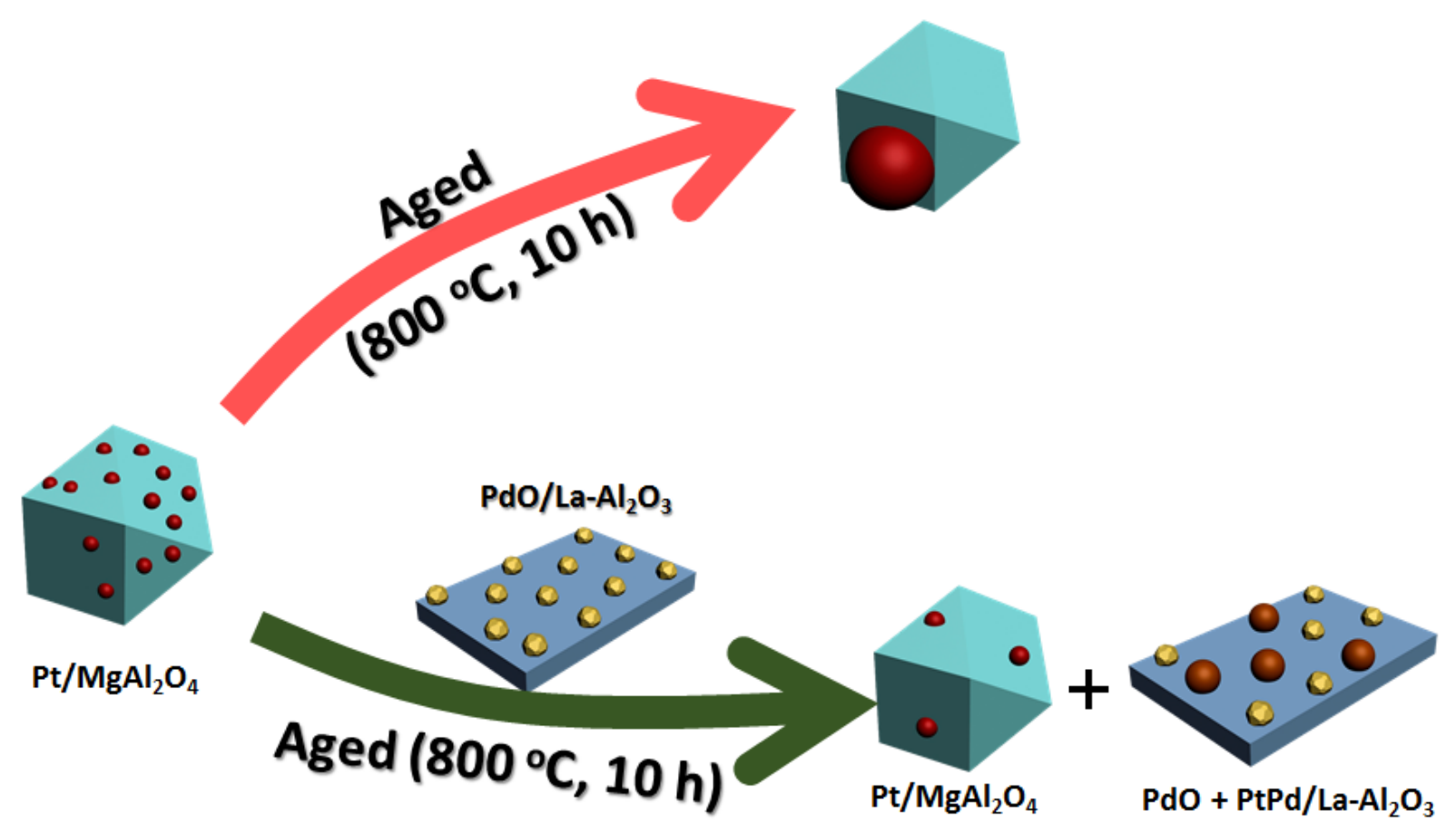

